\title{
Conference of Eastern College Librarians, 1945: Summary
}

\section{$\mathrm{T}$} HE THIRTY-SECOND Conference of Eastern College Librarians was called to order at IO:30 A.M., November 24, by Andrew D. Osborn, Harvard, chairman of the program committee. The location of the meeting had been transferred to McMillin Theatre because of the unexpectedly large attendance. Dr. Osborn turned the meeting over to Eileen M. Thornton, Vassar, who introduced the first speaker, Professor Jacques Barzun, whose paper, "The Scholar Looks at the Library," is printed in full on pages $113-17$.

In the discussion that followed it was brought out that Professor Barzun's conception of general knowledge chiefly involved the humanities rather than the sciences in which, he felt, knowledge was relatively well indexed. The problem of undergraduate indifference to libraries was brought up, and Professor Barzun suggested that if the teacher goes too far in inducing use of the library he is robbing the librarian of his proper function; students must be led to water and coaxed in, not thrown in. In connection with general knowledge, he complained of library book lists that combine the great works and the cheap popularizations, neglecting the intermediate, good popularizations. Apropos of the evils of the reserved book system, Professor Barzun thought that the lack of sufficient direct contact between librarian and teacher was not entirely to be blamed on either one.

\section{Publication of the Minutes}

Referring to the mimeographed history of the conference by Charles M. Adams, Woman's College, University of North Carolina, which had been distributed at the meeting, Dr. Osborn remarked that informality had always been one of the chief attractions of the conference and that there was no desire to restrict it to formal papers. There had, however, been recurrent demands for published proceedings. He thought that if a fairly detailed summary could be prepared the meeting would not be formalized but a record would be available. College and Research Libraries was believed to be ready to publish such a summary. There would be no obstacle to publication in full of some papers, as had been done in the past. In this connection it was suggested that there be a bibliography of published papers of former conferences. Dr. Osborn's motion that a summary of proceedings be prepared was approved.

\section{Foreign University Official Publications}

Eleanor M. Witmer, Teachers College, Columbia University, pointed out the need for cooperative effort in collecting and making available the official publications of foreign universities. These are important materials for the study of such matters as the history of education abroad, the curriculum, and the role of universities in cultural life; they are also important reference tools. Undoubtedly much material of this 
sort has been lost in Europe during the war, and there is no easy way to find out what has been published or how strong American collections are. Teachers College, last spring, sent out a preliminary letter to libraries in the area asking their policies in acquisition and handling of such publications. A number of institutions wish to collect them and to fill in present gaps in their holdings. Miss Witmer proposed that a small committee be appointed to study proposals for cooperative action. (At the afternoon session, the secretary announced that Miss Witmer, Dr. Osborn, and Charles F. Gosnell, New York State Library, had been named to serve on this committee.)

\section{Principles Underlying the New L.C. Cata- loging Rules}

Herman H. Henkle, Library of Congress, emphasized the fact that his paper was a tentative and incomplete summary of principles underlying the new rules for descriptive cataloging. The basic aims have been to fit the rules to the functions they must serve and to design an entry that will present an integrated description of the book and indicate clearly its relation to other editions and issues of the book and to other books recorded in the catalog. Six major principles of description are involved, as follows:

I. The book is generally to be described in the words or terms in which it is described by its author or publisher on the title page or elsewhere in the book. Ambiguous or unintelligible statements are to be followed by explanations, and inaccurate statements by appropriate corrections. Where the original statements are covered by labels bearing different statements, the original statements are to be given where possible, followed by indications of the label statements. Here, the chief question is as to how far the lack of uniformity in terminology of publishers is to be reproduced and how far the cataloger must substitute a terminology of his own.
2. The book is to be described as fully as required by the accepted functions but with an economy of data, words, and expressions. In transcribing from the title page no bibliographical item should be repeated, data of improbable value are to be omitted or curtailed, unnecessary words and phrases disregarded, and standard abbreviations used as provided. Here questions arise as to transcription of the author statement after the title and as to the character of the collation statement.

3. The bibliographical elements of the book are to be given on the entry in such order as will best respond to the normal approach of the reader and will be suited for integration of the entry with the entries of other books and other editions of the book in the catalog. The order selected for these purposes, following the author's name in the entry, is generally : title, subtitle, author statement, edition statement, place, publisher, and date of publication; followed by a statement of collation, series note, and supplementary notes. Questions arise here when, for example, the subtitle or the author statement, or both, appear on the title page before the title.

4. All information relating to a given bibliographical item should be integrated, except where the length or construction of a given statement makes its integration with the other data undesirable. In this case the statement may preferably be given in a note. There is general agreement on this principle, which will considerably reduce the number of notes to be used.

5. The sources of the data supplied by the cataloger in brackets in the main body of the entry need not be stated on its face, except when the data are supplied from unusual or other than standard sources, sources qualifying the meaning of the data (e.g., cover, preface, etc.), or disputed sources.

6 . If the title page is capitalized, punctuated, or accented in accordance with the style of the text of the book, it should be transcribed in the style given. If the style is of a typographical character, the title page should be capitalized, punctuated, and accented in accordance with the usage of the given language. Those who oppose this principle are unwilling to follow the capitalization of the title page except when it, as well as the text of the book. is all in lower case. 
Questions during the discussion brought out the fact that the A.L.A. definitions are being used almost entirely in connection with the new rules. It is anticipated that Part II of the proposed revised A.L.A. code, which has been held up pending completion of the Library of Congress rules, will not appear if these rules prove to be generally satisfactory.

\section{Some Aspects of Personnel Work in College Libraries}

Lucy E. Fay, Temple, suggested that many of the criticisms made by Professor Barzun in his book and in his paper earlier in the day call attention to shortcomings that grow out of poor personnel management. The organization of the work in college libraries has grown up through the years and has been centered about the assistants rather than determined by the objectives of the library. One means of getting away from this is to describe each position carefully and to define the qualifications needed in any assistant who is to fill it.

In selection of the staff, poor interviewing techniques are widespread. Appointment of assistants and notification of unsuccessful applicants should be handled in a businesslike manner. A good staff manual can contribute greatly to effective induction procedures. A classified, graded service for both clerical and professional assistants is an aid to successful personnel administration.

Individual development of staff members must be encouraged; physical health should be promoted by good working conditions with reasonable hours, ample work space, ventilation, lighting, and staff rooms. Opportunities for continuing education should be made available; an elevated conception of librarianship should be encouraged; and the staff must be made to realize its place in the educational program of the college.
Successful recruiting should be facilitated by personnel policies of this sort, particularly if members of the college administration and faculty can be shown the opportunities in librarianship and if fellowship can be provided on the same basis as for other fields.

\section{Afternoon Session}

Homer Halvorson, Johns Hopkins, presided at the afternoon session. He explained that Luther Evans was in London and that Verner W. Clapp, director of the Acquisitions Department of the Library of Congress, would present the first paper, "The Purchase of Books in Europe." Mr. Clapp's paper appears on pages 127-34.

Book and Library Affairs and the Program of an International Educational and Cultural Organization

Carl M. White, Columbia, emphasized the need of discussing the new organization and thus agreeing on what terms the United States could give its moral and financial support. Only the charter has been formulated thus far. The meeting in London was for organizational purposes. A preparatory commission will be at work on a program while the charter is being approved by the required twenty nations. The program of the new organization might well include:

I. A publications program, which will attempt to promote reference works that are needed but of such magnitude that cooperation is required to produce them, an increasing number of good translations, and machinery for bringing to light gaps that ought to be filled by publications.

2. The development of better arrangements for international distribution of books through copyright agreements, the reduction of trade barriers, and related efforts to facilitate ready access.

3. Promotion of the use of books internationally by encouraging the public library 
movement, facilitating international exchange of books, interlibrary loans, and microphotographic services (with a clearinghouse at the international level to gauge edition sizes), and development of good bibliographical apparatus, particularly indexing and abstracting services.

Mr. White hoped that the attention being given to the press, radio, and screen as media of "mass communication" would not obscure the fact that some tasks can best be done by books.

With regard to reconstruction and rehabilitation, he thought that the forthcoming campaign of the American Book Center deserved generous support. The center has now been financed and will attempt to collect one million suitable books. Reference was also made to the stockpiles assembled by the A.L.A. with the help of Rockefeller Foundation grants. Discussion called at- tention to the fact that the many individual requests for aid that are coming in ought to be cleared through the American Book Center.

\section{Buildings}

The paper by John E. Burchard, Massachusetts Institute of Technology, on postwar library buildings appears on pages I I 826. In the discussion that followed, the uncertainty of construction costs in the near future was emphasized. Attention was called to several new library building programs that had been processed and informally distributed, particularly those prepared at Wellesley, Pennsylvania, and the Massachusetts Institute of Technology. Mr. Burchard said that he would be glad to send a copy of the M.I.T. program to any librarian who requested it.

\section{G. L. S. Scholarships}

The Graduate Library School of the University of Chicago offers two scholarship awards of $\$ 450$ and one award of $\$ 300$ for the academic year $1946-47$ for students. in its basic library science curriculum. The tuition and fee charges for the academic year amount to $\$ 300$.

Applicants must have completed at least two years of college work; the curriculum subsequent to the first two years of college covers a three-year period. Persons with four years of college credit may also apply and, if successful, will receive the scholarship grant for the final year of professional study.

Forms for making application for scholarships may be obtained by writing the Graduate Library School, University of Chicago, Chicago 37. Applications must be submitted by June $15,1946$. 